\title{
Faktor-faktor yang Berhubungan dengan Kepuasan Pasien Tuberkulosis di Puskesmas Padang Bulan Medan
}

\author{
Ragil Sekar Kinanti Hutabarat \\ Program Studi IImu Kesehatan Masyarakat, Universitas Sari Mutiara Indonesia \\ J.. Kapten Muslim No 79, Medan 20123 \\ Email : ragilsekark@yahoo.com
}

\begin{abstract}
Abstrak
Tuberkulosis adalah penyakit menular langsung yang disebabkan oleh Mycobacterium tuberculosis.Sebagian besar dari kasus TB terjadi di negara berkembang. Di Indonesia, berdasarkan data Riskerdas tahun 2013, prevalensi penduduk Indonesia yang didiagnosis TB paru oleh tenaga kesehatan tahun 2013 adalah 0,4 persen, dengan lima provinsi dengan TB paru tertinggi adalah Jawa Barat $(0,7 \%)$, Papua (0,6\%), DKI Jakarta (0,6\%), Gorontalo (0,5\%), Banten $(0,4 \%)$ dan Papua Barat (0,4\%). Penelitian ini bertujuan untuk mengetahui faktor yang berhubungan dengan kepuasan pasien tuberkulosis serta mengetahui faktor yang paling dominan dalam kepuasan pasien tuberkulosis di Puskesmas Padang Bulan Medan Tahun 2017.Desain penelitian ini adalah Cross Sectional Study.Data diperoleh dari catatan rekam medis pasien serta dengan pengukuran langsung kepada responden.Besar sampel dalam penelitian ini adalah 122 responden. Hasil analisis bivariat menunjukkan berhubungan dengan kepuasan pasien tuberkulosis $(p<0,05)$. Berdasarkan hasil analisis Multivariat variabel dominan yang berhubungan dengan kepuasan pasien tuberkulosis adalah penjelasan/informasi medis oleh dokter dengan $p$-value $0,000(p<0,005)$, nilai OR sebesar $4 I, 43$ $(95 \% \mathrm{Cl} 5,09-337, \mathrm{II})$ dan lama waktu tunggu pelayanan dokter dengan $p$-value $0,000(p<0,005)$, nilai OR sebesar $27,88(95 \% \mathrm{Cl} 4,77$ - 162,92). Disimpulkan bahwa penjelasan/informasi medis oleh dokter dan lama waktu tunggu pelayanan dokter merupakan faktor yang sangat berhubungan dengan kepuasan pasien tuberkulosis.

Kata kunci : Determinan, Kepuasan Pasien, Tuberkulosis
\end{abstract}

\begin{abstract}
Tuberculosis is a communicable disease caused by Mycrobacterium tuberculosis. Most of the cases of tuberculosis occur in the development countries. In Indonesia, the data from Riskesdas in 2013 revealed that the prevalence of the Indonesian people who were diagnosed by the health care providers in 2013 as being affected by pulmonary tuberculosis were $0.4 \%$, and the highest prevalence was in West Java (0.7\%), followed by Papua (0.6\%), DKI Jakarta (0.6\%), Gorontalo (0.5\%), Banten (0.4\%), and West Papua (0.4\%). The objective of the research was to find out some factors which were correlated with tuberculosis patients' satisfaction and to find out the most dominant factor correlated with tuberculosis patients' satisfaction at Padang Bulan Puskesmas, Medan, in 2017. The research used cross sectional study. The data were gathered from patients'medical records and by direct measurement to the respondents. The samples were 122 respondents. The result of bivariate analysis showed that all independent variables were correlated with tuberculosis patients' satisfaction $(p<0.05)$. The result of multivariate analysis showed that the variables which had dominant correlation with tuberculosis patients' satisfaction were doctors' medical information/explanation ( $p$-value $=0.000(p<0.005 ; O R=41.4395 \% \mathrm{Cl} 5.09$ 337.I I) and waiting time for doctors' service ( $p$-value $=0.000(p<0.005 ; O R=27.8895 \% \mathrm{Cl}$ 4.77-I62.92). It was concluded that doctors;' medical information/explanation and waiting time for doctors' service were the variables which had the most dominant correlation with tuberculosis patients' satisfaction.

Keywords : Determinant, Patients Satisfaction, Tuberculosis
\end{abstract}




\section{Pendahuluan}

Tuberkulosis (TB) adalah penyakit menular langsung yang disebabkan oleh Mycobacterium Tuberculosis. Kuman ini umumnya menyerang paru, namun dapat pula mengenai organ tubuh lain. Tuberkulosis sudah menjadi permasalahan kesehatan jutaan orang di dunia.Tuberkulosis menjadi penyebab utama kedua kematian dari penyakit menular di seluruh dunia, setelah Human Immunodeficiency Virus (HIV). ${ }^{1}$

Di Indonesia, berdasarkan data Riskesdas tahun 2013, prevalensi penduduk Indonesia yang didiagnosis TB paru oleh tenaga kesehatan tahun 2013 adalah 0,4 persen, dengan lima provinsi dengan TB paru tertinggi adalah Jawa Barat $(0,7 \%)$, Papua $(0,6 \%)$, DKI Jakarta (0,6\%), Gorontalo (0,5\%), Banten (0,4\%) dan Papua Barat (0,4\%). Proporsi penduduk dengan gejala TB paru batuk $\geq 2$ minggu sebesar 3,9 persen dan batuk darah 2,8 persen (Litbangkes, 2013), sedangkan berdasarkan Angka Notifikasi Kasus atau Case Notification Rate (CNR), angka notifikasi kasus BTA (+) pada tahun 2013 di Indonesia sebesar 81,0 per 100.000 penduduk. ${ }^{1}$

Berdasarkan jumlah penduduk 2014, diperhitungkan sasaran penemuan kasus baru TB paru BTA (+) di Provinsi Sumatera Utara adalah sebesar 22.026 jiwa dan hasil cakupan penemuan kasus baru TB Paru BTA (+) 1.818 kasus atau 76,35\%. Angka ini mengalami peningkatan bila dibandingkan dengan cakupan penemuan kasus baru tahun 2013 sebesar 72,29\%. Pada tahun 2014, CNR kasus baru TB Paru BTA (+) Sumatera Utara mencapai 122/100.000 penduduk. ${ }^{2}$

Puskesmas Padang Bulan Medan letaknya strategis didalam kota dan dapat dijangkau denganangkutan umum. Berdasarkan hasil catatan kegiatan Puskesmas Padang Bulan Medan Tahun 2016, kunjungan penderita berasal dari beberapa kelurahan di wilayah kerja Puskesmas Padang Bulan Medan seperti Kelurahan Titi Rantai, Kelurahan Padang
Bulan, Kelurahan Merdeka, Kelurahan Darat, Kelurahan Babura, Kelurahan Petisah Hulu dan pasien dari Kelurahan luar wilayah.Berdasarkan survey yang dilakukan di Puskesmas Padang Bulan Medan diperoleh datamengenai jumlah penderita TB pada tahun 2016 adalah sebesar 104 penderita dengan kasus kambuh sebanyak 4 orang.

Pengobatan tuberkulosis paru yang lama dapat menyebabkan penderita mengalami drop out dalam program pengobatan sehingga tidak sesuai dengan standar,hal ini menyebabkan masalah dalam penanggulangannya. Untuk mengatasi permasalahan tersebut dibutuhkan adanya tempat pelayanan kesehatan yang memberikan pelayanan sesuai dengan kebutuhan dan harapan pasien sehingga pasien merasa puas dan cenderung akan mengikuti program pengobatan yang sedang dijalani.

Berdasarkan keluhanpasien yang dikelola melalui kotak saran di Puskesmas Padang Bulan Medan ditemukan bahwa terdapat keluhan tentang kurangnya empati petugas dalam memberikan pelayanan, dokter yang memeriksa terkesan terburu-buru, petugas yang datang terlambat dan kurangnya kecepatan dalam memberikan pelayanan. Berdasarkan survey yang peneliti lakukan didapatkan dari 10 orang pasien terdapat 6 orang menyatakan puas dan 4 orang yang menyatakan tidak puas terhadap pelayanan yang diberikan di Puskesmas Padang Bulan Medan.

\section{Metode Penelitian}

Penelitian ini menggunakan pendekatan cross sectional dengan metode penelitian kuantitatif yang bertujuan untuk menganalisa tingkat kepuasan pasien tuberkulosis dan faktor-faktor yang berhubungan dengan kepuasan pasien tuberkulosis di Puskesmas Padang Bulan Medan tahun 2017.

Populasi dalam penelitian ini adalah pasien yang menderita Tuberkulosis yang berobat di Puskesmas Padang Bulan 
Medan pada bulan Juli sampai September 2017 sebanyak 122 orang pasien. Sedangkan sampel yang digunakan peneliti ialah seluruh pasien tuberkulosis yang berkunjung ke Puskesmas Padang Bulan Medan dengan menggunakan teknik pengambilan Accidental Sampling dan besar sampel pada penelitian ini penulis menggunakan total populasi yaitu sebanyak 122 orang.

\section{Hasil}

Tabel 1. Analisis Univariat

\begin{tabular}{llcc}
\hline \multicolumn{1}{c}{ Variabel } & \multicolumn{1}{c}{ Kategori } & n & \% \\
\hline Jenis & Laki-Laki & 74 & 60,7 \\
Kelamin & Perempuan & 48 & 39,3 \\
Umur & 19-36 Tahun & 43 & 35,2 \\
& 37-54 Tahun & 62 & 50,8 \\
& 55-70 Tahun & 17 & 14,0 \\
Pendidikan & SMP & 19 & 15,6 \\
Terakhir & SMU & 82 & 67,2 \\
& Akademi & 3 & 2,5 \\
Kepuasan & PT & 18 & 14,7 \\
Pasien & Tidak puas & 27 & 22,1 \\
Penghasilan & Puas & 95 & 77,9 \\
& $\geq$ Rp 2.500.000 & 40 & 32,8 \\
Kenyamanan & T Rp 2.500.000 & 82 & 67,2 \\
& Tidak nyaman & 18 & 14,8 \\
Kecepatan & Nyaman & 104 & 85,2 \\
Pelayanan & $\geq 30$ menit & 19 & 15,6 \\
Sikap & T30 menit & 103 & 84,4 \\
Perawat & Ridak ramah & 17 & 13,9 \\
Lama Waktu & $\geq 30$ menit & 105 & 86,1 \\
Tunggu & $<30$ menit & 96 & 21,3 \\
Sikap Dokter & Tidak ramah & 18 & 78,7 \\
& Ramah & 104 & 85,2 \\
Penjelasan & Tidak jelas & 17 & 13,9 \\
Medis & Jelas & 105 & 86,1 \\
Waktu & $\geq 30$ menit & 15 & 12,3 \\
Tunggu Obat & $<30$ menit & 107 & 87,7 \\
\hline & & & \\
& & &
\end{tabular}

Tabel 1 menunjukkan bahwa mayoritas jenis kelamin responden adalah laki-laki (60,7\%). Berdasarkan umur responden mayoritas adalah umur 37-54 tahun $(50,8 \%)$ dan berdasarkan pendidikan terakhir mayoritas responden adalah pendidikan SMU $(67,2 \%)$.

Proporsi kepuasan pasien tuberkulosis di Puskesmas Padang Bulan Medan tahun 2017 sebagian kecil menyatakan tidak puas terhadap pelayanan di Puskesmas yaitu 27 orang (22,1\%) dan sebanyak 95 orang (77,9\%) menyatakan puas terhadap pelayanan di Puskesmas. Distribusi frekuensi menurut penghasilan keluarga pasien tuberkulosis di Puskesmas Padang Bulan Medan Tahun 2017 sebagian besar dengan penghasilan $<$ Rp 2.500.000 yaitu 82 orang $(67,2 \%)$ dan sebanyak 40 orang (32,8\%) dengan penghasilan $\geq \mathrm{Rp}$ 2.500.000. Distribusi frekuensi menurut kenyamanan puskesmas pada pasien tuberkulosis di Puskesmas Padang Bulan Medan Tahun 2017 sebagian besar nyaman yaitu 104 orang $(85,2 \%)$ dan sebanyak 18 orang $(14,8 \%)$ tidak nyaman. Distribusi frekuensi menurut kecepatan pelayanan di pendaftaran pada pasien tuberkulosis di Puskesmas Padang Bulan Medan Tahun 2017 sebagian besar mendapatkan pelayanan < 30 menit yaitu 103 orang $(84,4 \%)$ dan sebanyak 19 orang $(15,6 \%)$ mendapatkan pelayanan $\geq 30$ menit. Distribusi frekuensi menurut sikap perawat yang diterima pasien tuberkulosis di Puskesmas Padang Bulan Medan Tahun 2017 sebagian besar ramah yaitu 105 orang (86,1\%) dan sebanyak 7 orang (13,9\%) dengan sikap tidak ramah. Distribusi frekuensi menurut lama waktu tunggu pelayanan dokter pada pasien tuberkulosis di Puskesmas Padang Bulan Medan Tahun 2017 sebagian besar menunggu pelayanan dokter < 30 menit yaitu 96 orang (78,7\%) dan sebanyak 26 orang (21,3\%) menunggu pelayanan dokter $\geq 30$ menit. Distribusi frekuensi menurut sikap dokter yang diterima pasien tuberkulosis di Puskesmas Padang Bulan Medan Tahun 2017 sebagian besar ramah yaitu 104 orang $(85,2 \%)$ dan sebanyak 18 orang $(14,8 \%)$ dengan sikap tidak ramah.

Distribusi frekuensi menurut penjelasan/informasi medis oleh dokter pada pasien tuberkulosis di Puskesmas Padang Bulan Medan Tahun 2017 sebagian besar mendapatkan penjelasan yang jelas yaitu 112 orang $(88,2 \%)$ dan sebanyak 15 orang $(11,8 \%)$ mendapatkan penjelasan yang tidak jelas. Distribusi frekuensi menurut lama waktu tunggu pengambilan 
obat pada pasien tuberkulosis di Puskesmas Padang Bulan Medan Tahun 2017 sebagian besar menunggu pengambilan obat < 30 menit yaitu 107 orang $(87,7 \%)$ dan sebanyak 15 orang $(12,3 \%)$ menunggu pengambilan obat $\geq 30$ menit.

\section{Analisis Bivariat}

Tabel 2 menunjukkan bahwa proporsi pasien tuberkulsosis di Puskesmas Padang Bulan Medan Tahun 2017 bahwa : Terdapat hubungan yang bermakna antara faktor penghasilan keluarga dan kepuasan pasien tuberkulosis di Puskesmas Padang Bulan Medan Tahun $2017(\mathrm{P}<0,05)$, dengan OR=8,36 (95\% CI: 3,21-21,80). Kepuasan pasien di Puskesmas Padang Bulan Medan Tahun 2017 8,36kali lebih tinggi pada pasien dengan penghasilan < Rp 2.500.000/bulan daripada pasien dengan penghasilan $\geq$ Rp 2.500.000/bulan dengan interval kepercayaan antara3,2121,80 . Terdapat hubungan yang bermakna antara faktor kenyamanan puskesmas dan kepuasan pasien tuberkulosis di Puskesmas Padang Bulan Medan Tahun 2017 $(\mathrm{P}<0,05)$, dengan $\mathrm{OR}=38,33 \quad(95 \% \mathrm{CI}$ : 9,66-152,0). Kepuasan pasien di Puskesmas Padang Bulan Medan Tahun
2017 38,33kali lebih tinggi pada pasien dengan perasaan yang nyaman daripada pasien dengan perasaan yang tidak nyaman terhadap lingkungan puskesmas dengan interval kepercayaan antara 9,66-152,0. Terdapat hubungan yang bermakna antara faktor kecepatan pelayanan di pendaftaran dan kepuasan pasien tuberkulosis di Puskesmas Padang Bulan Medan Tahun $2017(\mathrm{P}<0,05)$, dengan $\mathrm{OR}=19,38 \quad(95 \%$ CI: 5,98-62,77). Kepuasan pasien di Puskesmas Padang Bulan Medan Tahun 2017 19,38 kali lebih tinggi pada pasien dengan kecepatan pelayanan $<30$ menit daripada pasien dengan pelayanan $\geq 30$ menit dengan interval kepercayaan antara5,98-62,77. Terdapat hubungan yang bermakna antara faktor sikap perawat dan kepuasan pasien tuberkulosis di Puskesmas Padang Bulan Medan Tahun 2017 $(\mathrm{P}<0,05)$, dengan $\mathrm{OR}=14,40 \quad(95 \% \quad \mathrm{CI}$ : 4,43-46,76).

Kepuasan pasien di Puskesmas Padang Bulan Medan Tahun 2017 14,40 kali lebih tinggi pada sikap perawat yang ramah daripada sikap perawat yang tidak ramah pada pasien dengan interval kepercayaan antara 4,43-46,76.

Tabel 2. Hubungan Variabel Independen yang Diteliti dengan Kepuasan Pasien Tuberkulosis di Puskesmas Padang Bulan Medan Tahun 2017

\begin{tabular}{|c|c|c|c|c|c|c|c|}
\hline \multirow{3}{*}{ Variabel } & \multirow{3}{*}{ Kategori } & \multicolumn{4}{|c|}{ Kepuasan Pasien } & \multirow{3}{*}{$\mathbf{P v}$} & \multirow{3}{*}{ OR } \\
\hline & & \multicolumn{2}{|c|}{ Tidak Puas } & \multicolumn{2}{|c|}{ Puas } & & \\
\hline & & $\mathbf{n}$ & $\%$ & $\mathbf{n}$ & $\%$ & & \\
\hline \multirow{2}{*}{ Penghasilan } & $\geq \operatorname{Rp} 2.500 .000$ & 19 & 15,6 & 21 & 17,2 & \multirow{2}{*}{0,000} & \multirow{2}{*}{8,36} \\
\hline & $<$ Rp2.500.000 & 8 & 6,6 & 74 & 60,7 & & \\
\hline \multirow[t]{2}{*}{ Kenyamanan } & Tidak nyaman & 15 & 12,3 & 3 & 2,5 & \multirow{2}{*}{0,000} & \multirow{2}{*}{38,33} \\
\hline & Nyaman & 12 & 9,8 & 92 & 75,4 & & \\
\hline \multirow[t]{2}{*}{ Pelayanan } & $\geq 30$ menit & 14 & 11,5 & 5 & 4,1 & \multirow{2}{*}{0,000} & \multirow{2}{*}{19,38} \\
\hline & $<30$ menit & 13 & 10,7 & 90 & 73,8 & & \\
\hline \multirow[t]{2}{*}{ Sikap } & Tidak ramah & 12 & 9,8 & 5 & 4,1 & \multirow{2}{*}{0,000} & \multirow{2}{*}{14,40} \\
\hline & Ramah & 15 & 12,3 & 90 & 73,8 & & \\
\hline \multirow[t]{2}{*}{ Waktu tunggu } & $\geq 30$ menit & 19 & 15,6 & 7 & 5,7 & \multirow{2}{*}{0,000} & \multirow{2}{*}{29,85} \\
\hline & $<30$ menit & 8 & 6,6 & 88 & 72,1 & & \\
\hline \multirow[t]{2}{*}{ Sikap dokter } & Tidak ramah & 12 & 9,8 & 6 & 4,9 & \multirow{2}{*}{0,000} & \multirow{2}{*}{11,86} \\
\hline & Ramah & 15 & 12,3 & 89 & 73,0 & & \\
\hline \multirow{2}{*}{$\begin{array}{l}\text { Penjelasan } \\
\text { medis }\end{array}$} & Tidak jelas & 14 & 11,5 & 3 & 2,5 & \multirow{2}{*}{0,000} & \multirow{2}{*}{33,02} \\
\hline & Jelas & 13 & 10,7 & 92 & 75,4 & & \\
\hline Waktu tunggu & $\geq 30$ menit & 12 & 9,8 & 3 & 2,5 & \multirow{2}{*}{0,000} & \multirow{2}{*}{24,53} \\
\hline obat & $<30$ menit & 15 & 12,3 & 92 & 75,4 & & \\
\hline
\end{tabular}


Terdapat hubungan yang bermakna antara faktor lama waktu tunggu pelayanan dokter dan kepuasan pasien tuberkulosis di Puskesmas Padang Bulan Medan Tahun $2017(\mathrm{P}<0,05)$, dengan $\mathrm{OR}=29,85 \quad(95 \%$ CI: 9,65-92,34). Kepuasan pasien di Puskesmas Padang Bulan Medan Tahun 2017 2,85kali lebih tinggi pada waktu tunggu pelayanan dokter $<30$ menit daripada waktu tunggu $\geq 30$ menit dengan interval kepercayaan antara 9,6592,34.Terdapat hubungan yang bermakna antara faktor sikap dokter dan kepuasan pasien tuberkulosis di Puskesmas Padang Bulan Medan Tahun $2017(\mathrm{P}<0,05)$, dengan OR=11,86 (95\% CI: 3,86-36,45). Kepuasan pasien di Puskesmas Padang Bulan Medan Tahun 2017 11,86kali lebih tinggi pada sikap dokter yang ramah daripada sikap dokter yang tidak ramah dengan interval kepercayaan antara3,8636,45 .

Terdapat hubungan yang bermakna antara faktor penjelasan/informasi medis oleh dokter dan kepuasan pasien tuberkulosis di Puskesmas Padang Bulan Medan Tahun $2017 \quad(\mathrm{P}<0,05)$, dengan $\mathrm{OR}=33,02 \quad(95 \% \quad \mathrm{CI}: \quad 8,34-130,69)$. Kepuasan pasien di Puskesmas Padang Bulan Medan Tahun 2017 33,02kali lebih tinggi pada penjelasan/informasi medis secara jelas daripada penjelasan medis secara tidak jelas oleh dokter dengan interval kepercayaan antara 8,34-130,69. Terdapat hubungan yang bermakna antara faktor lama waktu tunggu pengambilan obat dan kepuasan pasien tuberkulosis di Puskesmas Padang Bulan Medan Tahun $2017(\mathrm{P}<0,05)$, dengan $\mathrm{OR}=24,53 \quad(95 \%$ CI: 6,18-97,30). Kepuasan pasien di Puskesmas Padang Bulan Medan Tahun
2017 24,53kali lebih tinggi pada waktu tunggu pengambilan obat $<30$ menit daripada waktu tunggu $\geq 30$ menit dengan interval kepercayaan antara 6,18-97,30.

\section{Analisis Multivariat}

Variabel yang terpilih dalam model akhir regresi logistik berganda dengan model enter seperti diujikan pada Tabel 3. Berdasarkan hasil analisis regresi logistik, variabel kecepatan pelayanan di pendaftaran diperoleh nilai OR sebesar25,70 artinyakecepatan pelayanan $<30$ menit 25,70 kali lebih besar hubungannya dengan kepuasan pasientuberkulosis dibandingkan dengan pasien yang mendapatkan pelayanan $\geq 30$ menit.Variabel lama waktu tunggu pelayanan doker diperoleh dengan nilai OR sebesar 27,88 artinya lama waktu tunggu pelayanan dokter $<30$ menit 27,88 kali lebih besar hubungannya dengan kepuasan pasien tuberkulosis dibandingkan dengan lama waktu tunggu pelayanan $\geq 30$ menit. Variabel sikap dokter diperoleh nilai OR sebesar6,49artinya sikap dokter yang ramah6,49kali lebih besar hubungannya dengan pasien kepuasan pasien tuberkulosisdibandingkan dengan sikap dokter yang tidak ramah yang diterima oleh pasien. Variabel penjelasan/informasi medis oleh dokter diperoleh nilai OR sebesar41,43artinya penjelasan/informasi medis oleh dokter secara jelas $41,43 \mathrm{kali}$ lebih besar hubungannya dengan kepuasan pasien tuberkulosisdibandingkan dengan penjelasan/informasi medis oleh dokter secara tidak jelas.

Tabel 3. Hasil Akhir Regresi Logistik Berganda

\begin{tabular}{llllc}
\hline \multicolumn{1}{c}{ Variabel } & B & p-value & OR & 95 \% CI \\
\hline Kecepatan Pelayanan & 3,247 & 0,001 & 25,70 & $3,55-185,92$ \\
Waktu Tunggu Pelayanan Dokter & 3,328 & 0,000 & 27,88 & $4,77-162,92$ \\
$\begin{array}{l}\text { Sikap dokter } \\
\text { Penjelasan medis Oleh Dokter }\end{array}$ & 1,871 & 0,049 & 6,49 & $1,00-41,95$ \\
Constant & 3,724 & 0,000 & 41,43 & $5,09-337,11$ \\
& $-7,913$ & 0,000 & & \\
\hline
\end{tabular}




\section{Pembahasan}

\section{Hubungan Faktor Penghasilan Keluarga dengan Kepuasan Pasien Tuberkulosis}

Berdasarkan hubungan faktor penghasilan keluarga dan kepuasan pasien tuberkulosis di Puskesmas Padang Bulan Medan diperoleh dari 40 orang responden yang memiliki penghasilan $\geq \mathrm{Rp}$ 2.500.000/bulan, 19 orang (15,6\%) menyatakan tidak puas dan 21 orang $(17,2 \%)$ menyatakan puas sedangkan dari 82 responden yang memiliki penghasilan < Rp 2.500.000/bulan yang menyatakan tidak puas sebanyak 8 orang $(6,6 \%)$ dan 74 orang $(60,7 \%)$ menyatakan puas. Hasil uji statistik dengan uji Chi Square menunjukkan ada hubungan yang signifikan antara faktor penghasilankeluarga dan kepuasan pasien $(\mathrm{p}<0,005)$.

Hasil penelitian ini didukung juga oleh Budiman tahun 2012, dkk yang menyatakan hasil penelitian bahwa ada hubungan yang signifikan antara penghasilan dan kepuasan pasien.Berdasarkan penelitian, daya beli masyarakat sangat dipengaruhi oleh penghasilan. Jika penghasilan yang diperoleh kecil maka kebutuhan pelayanan kesehatan yang ia dapatkan lebih sedikit atau dibawah rata-rata. Sebaliknya, jika seseorang mendapatkan penghasilan yang besar maka kebutuhan pelayanan kesehatan yang ia dapatkan akan lebih banyak. $^{3}$

\section{Hubungan Faktor Kenyamanan Puskesmas dengan Kepuasan Pasien Tuberkulosis}

Hasil analisis antara hubungan faktor kenyamananpuskesmas dan kepuasan pasien tuberkulosis di Puskesmas Padang Bulan Medan diperoleh dari 18 orang responden yang merasa tidak nyaman didapatkan 15 orang (12,3\%) yang menyatakan tidak puas dan 3 orang $(2,5 \%)$ menyatakan puas sedangkan dari 104 orang responden yang merasa nyaman dengan lingkungan puskesmas didapatkan 12 orang $(9,8 \%)$ menyatakan tidak puas dan 92 orang $(75,4 \%)$ menyatakan puas, sedangkan Hasil uji statistik dengan uji Chi Square menunjukkanada hubungan yang signifikan antara faktor kenyamanan dan kepuasan pasien $(\mathrm{p}<0,005)$.

Hasil penelitian ini sesuai dengan penelitian yang dilakukan oleh Hariyanti tahun 2012 tentang hubungan kenyamanan pasien dengan kepuasaan pasien di unit rawat inap RSUD Arifin Nu'mang Kab.Sidrap. Hasil penelitian ini menunjukan bahwa distribusi responden berdasarkan kepuasan sebagian besar menyatakan cukup puas terhadap aspek kenyamanan (80,3\%), berdasarkan hasil analisis hubungan dengan uji chisquare $(p<0,05)$ menunjukan ada hubungan antara kenyamanan $(\mathrm{p}=0,000)$ dengan kepuasaan pasien. ${ }^{4}$

\section{Hubungan Faktor Kecepatan Waktu Pelayanan di Pendaftaran dengan Kepuasan Pasien Tuberkulosis}

Berdasarkan hubungan faktor kecepatan waktu pelayanan di pendaftaran dan kepuasan pasien tuberkulosis di Puskesmas Padang Bulan Medandiperoleh dari 19 orang responden dengan kecepatan pelayanan di pendaftaran $\geq 30$ menit yang menyatakan tidak puas 14 orang (11,5\%) dan yang menyatakan puas sebanyak 5 orang (4,1\%) sedangkan dari 103 orang responden dengan kecepatan pelayanan di pendaftaran $<30$ menit yang menyatakan tidak puas 13 orang $(10,7 \%)$ dan menyatakan puas 90 orang $(73,8 \%)$. Hasil uji statistik dengan uji Chi Squaremenunjukkanada hubungan yang signifikan antara faktor kecepatan waktu pelayanan di pendaftaran dan kepuasan pasien $(p<0,005)$.

Dimensi ketepatan waktu, menjelaskan bahwa agar berhasil, layanan kesehatan itu harus dilaksanakan dalam waktu dan cara yang tepat, oleh pemberi pelayanan yang tepat, dan menggunakan peralatan dan obat yang tepat, serta biaya yang efisien. Ketepatan waktu dalam pelayanan merupakan kemampuan rumah sakit memberikan pelayanan sesuai dengan 
yang dijanjikan, yaitu meliputi kecepatan dan ketepatan petugas didalam memberikan pelayanan meliputi: ketepatan dalam prosedur penerimaan pasien, pendaftaran, dan waktu menunggu. ${ }^{5}$

\section{Hubungan Faktor Sikap Perawat dengan Kepuasan Pasien Tuberkulosis}

Berdasarkan hubungan faktor sikap perawatdan kepuasan pasien tuberkulosis di Puskesmas Padang Bulan Medan diperoleh dari 17orang responden yang menyatakan sikap perawat tidak ramah yang menyatakan tidak puas sebanyak12 orang $(9,8 \%)$ dan 5 orang $(4,1 \%)$ menyatakan puas, sedangkan dari 105 orangresponden yang menyatakan sikap perawat ramah, 15orang (12,3\%) menyatakan tidak puas dan 90 orang $(73,8)$ menyatakan puas. Hasil uji statistik dengan uji Chi Square menunjukkanada hubungan yang signifikan antara faktor sikap perawatdan kepuasan pasien $(\mathrm{p}<0,005)$.

Berdasarkan hasil uji statistik dengan uji rank spearman diperoleh hasil bahwa nilai $p$ value 0,001. Jadi, keputusannya adalah Ho ditolak dan $\mathrm{Ha}$ diterima, sehingga dapat disimpulkan bahwa ada hubungan sangat signifikan antara perilaku petugas dengan kepuasan pasien.Perilaku petugas adalah pendapat responden terhadap perilaku petugas dalam melayani pasien yang mendaftar yang meliputi pertanyaan (petugas ramah saat melayani pasien, petugas sabar saat melayani pasien, petugas sopan saat melayani pasien, petugas berpenampilan rapi saat melayani pasien, petugas memberikan senyum saat melayani pasien). ${ }^{6}$

\section{Hubungan Faktor Lama Waktu Tunggu Pelayanan Dokter dengan Kepuasan Pasien Tuberkulosis}

Hasil analisis antara hubungan faktor lama waktu tunggu pelayanan dokter dan kepuasan pasien tuberkulosis di Puskesmas Padang Bulan Medan diperoleh dari 28 orang responden dengan lama waktu tunggu pelayanan dokter $\geq 30$ menit, 19 orang (15,6\%) menyatakan tidak puas dan 7 orang (5,7\%) menyatakan puas sedangkan dari 96orangresponden dengan lama waktu tunggu pelayanan dokter $<30$ menit yang menyatakantidak puas sebanyak 8 orang $(6,6 \%)$ dan 88 orang (72,1\%) menyatakan puas. Hasil uji statistik dengan uji Chi Square menunjukkan ada hubungan yang signifikan antara faktor lama waktu tunggu pelayanan dokter dan kepuasan pasien $(\mathrm{p}<0,005)$.

Ada hubungan antara waktu tunggu pelayanan dokter dan kepuasan pasien. Menurut Candra dalam Khairani, salah satu indikator sehingga menjadikan mereka pelanggan setia baik itu kepuasan pasien adalah waktu tunggu, waktu tunggu yang untuk kepentingan mereka pribadi ataupun dalam bentuk lama terhadap pelayanan medis maupun non medis pada rekomendasi (word of mouth) kepada sanak saudara, unit rawat jalan dan rawat inap akan mengurangi kepuasan pasien. Masalah yang sering muncul hubungan bermakna antara tingkat kepuasan pasien diinstalasi rawat jalan adalah lamanya waktu tunggu.Waktu tunggu adalah keseluruhan waktu yang dihabiskan oleh pasien dalam menunggu suatu layanan rawat jalan mulai dari pertama kali pasien melakukan pendaftaran di bagian pendaftaran hingga pemeriksaan pasien oleh dokter, dan waktu yang berlalu antara waktu perjanjian yang telah ditetapkan hingga pasien mendapatkan evaluasi. Waktu tunggu yang lama akan dapat menurunkan kepuasan pasien karena terjadi kesenjangan antara expected service dan perceived service. Kepuasan pasien dipengaruhi oleh kualitas layanan yang tergantung pada mempengaruhi kepuasan pasien di instalasi rawat jalan kemampuan penyedia jasa dalam memenuhi harapan rumah sakit. ${ }^{7}$

\section{Hubungan Faktor Sikap Dokter dengan Kepuasan Pasien Tuberkulosis}

Berdasarkan hubungan faktor sikap dokter dan kepuasan pasien tuberkulosis di 
Puskesmas Padang Bulan Medan diperoleh dari 18 orangresponden yang menyatakan dokter dengan sikap tidak ramah yang menyatakan tidak puas sebesar 12 orang $(9,8 \%)$ dan 6 orang (4,9\%) menyatakan puas sedangkan 104orang responden yang menyatakan dokter dengan sikap ramah yang menyatakan tidak puas sebanyak 15 orang (12,3\%) dan 89 orang (73,0\%) menyatakan puas. Hasil uji statistik dengan uji Chi Square menunjukkanada hubungan yang signifikan antara faktor sikap dokterdan kepuasan pasien $(\mathrm{p}<0,005)$.

Hasil penelitian ini sesuai dengan penelitian yang dilakukan oleh Wibawani tahun 2013, dkkhasil uji statistik dengan menggunakan uji chi square diperoleh nilai $\mathrm{p}=0,019$, karena nilai $\mathrm{p}<0,05$, hal ini berarti ada pengaruh antar manusia terhadap kepuasan pasien. Adapun responden yang puas terhadap hubungan antar manusia yang baik sebanyak 67 orang $(82.7 \%)$, hal ini dikarenakan dokter dan perawat selalu memberikan motivasi kepada pasien tentang kesembuhan penyakit yang dideritanya, selain itu dokter dan perawat dianggap selalu memahami kebutuhan mereka sebagai pasien. Sedangkan responden yang tidak puas walaupun hubungan antar manusia yang dirasakan baik sebanyak 14 orang (17.3\%), responden dalam kategori ini merasa bahwa dokter dan perawat sangat tanggap terhadap keluhan pasien, namun ada beberapa perawat yang kadang kurang ramah ketika melayani pasien, sehingga menyebankan mereka tidak puas. ${ }^{5}$

\section{Hubungan Faktor Penjelasan/Informasi Medis Oleh Dokter dengan Kepuasan Pasien Tuberkulosis Padang Bulan Medan Tahun 2017}

Hasil analisis antara hubungan faktor penjelasan/informasi medis oleh dokter dan kepuasan pasien tuberkulosis di Puskesmas Padang Bulan Medandiperoleh dari 17orang respondenyang menerima informasi secara tidak jelas dari dokter, 14 orang $(11,5 \%)$ merasa tidak puas dan 3 orang $(2,5 \%)$ menyatakan puas sedangkan dari 105orangresponden yang menerima informasi secara jelas dari dokter yang menyatakan tidak puas 13 orang (10,7\%) dan 92 orang $(75,4 \%)$ menyatakan puas. Hasil uji statistik dengan uji Chi Square menunjukkanada hubungan yang signifikan antara faktor penjelasan/informasi medis oleh dokter dan kepuasan pasien $(\mathrm{p}<0,005)$.

Hasil penelitian ini sejalan oleh Wibawani tahun 2013, dkk yang menyatakan bahwa adanya hubungan yang bermakna antara penjelasan/informasi medis dengan kepuasan pasien dengan nilai $\mathrm{P}=0,012$. karena nilai $\mathrm{p}<0,05$, hal ini berarti ada pengaruh informasi terhadap kepuasan pasien. ${ }^{5}$

\section{Hubungan Lama Waktu Tunggu Pengambilan Obat dengan Kepuasan Pasien Tuberkulosis}

Hasil analisis antara hubungan faktor lama waktu tunggu pengambilan obat dan kepuasn pasien tuberkulosis di Puskesmas Padang Bulan Medandiperoleh dari 15orangresponden dengan waktu pengambilan obat $\geq 30$ menit , 12 orang $(9,8 \%)$ merasa tidak puas dan 3 orang (2,5\%) merasa puas sedangkan dari 107 orang responden dengan waktu pengambilan obat $<30$ menit yang merasa tidak puas 15 orang $(12,3 \%)$ dan 92 orang $(75,4 \%)$ merasa puas. Hasil uji statistik dengan uji Chi Square menunjukkanada hubungan yang signifikan antara faktor lama waktu tunggu pengambilan obat dan kepuasan pasien $(\mathrm{p}<0,005)$.

Ada hubungan yang bermakna antara pelayanan farmasi dengan kepuasan pasien rawat inap di Rumah Sakit Islam Surakarta. ${ }^{8}$ Hal ini sesuai dengan penelitian yang dilakukan oleh Harianto tahun 2005tentang kepuasan pasien terhadap pelayanan apotek.Dimana dengan pelayanan yang cepat, ramah dan keterangan yang jelas serta kenyamanan ruang tunggu memberikan kepuasan terhadap pasien yang membutuhkan pelayanan. $^{9}$ 


\section{Kesimpulan}

Berdasarkan hasil penelitian dan pembahasan dapat diambil beberapa kesimpulan bahwa pada tahap analisis bivariat terdapat hubungan antara variabel penghasilan keluarga, kenyamanan puskesmas, kecepatan pelayanan di pendaftaran, sikap perawat, lama waktu tunggu pelayanan dokter, sikap dokter, penjelasan/informasi medis oleh dokter dan lama waktu tunggu pengambilan obat dengan kepuasan pasien tuberkulosis di Puskesmas Padang Bulan Medan Tahun 2017.

Variabel yang paling berhubungan terhadap kepuasan pasien tuberkulosis di Puskesmas Padang Bulan Medan Tahun 2017 adalah penjelasan/informasi medis oleh dokter dengan nilai OR 41,43 dan lama waktu tunggu pelayanan dokter dengan nilai OR 27,88.

\section{Saran}

Bagi Tenaga Kesehatan , khususnya untuk dokter penanggungjawab agar lebih dapat meningkatkan sikap yang ramah, perduli dan tanggap memberi informasi medis yang berkaitan dengan penyakit pasien secara jelas kepada pasien tuberkulosis di Puskesmas Padang Bulan Medan.

Bagi pihak puskesmas, khususnya kepala puskesmas agar lebih memperhatikan tugas dari setiap tenaga kerja, dan mencoba menyusun peraturan mengenai waktu pelayanan pasien mulai dari proses pendaftaran, waktu untuk mendapatkan pelayanan dokter sampai proses pengambilan obat. Kenyamanan pasien saat berada di dalam lingkungan puskesmas adalah hal yang tidak kalah pentingnya, maka dengan itu untuk meningkatkan rasa nyaman yang dirasakan pasien, pihak puskesmas bisa mencoba untuk menambah petugas kebersihan agar terciptanya lingkungan yang bersih, nyaman dan segar di puskesmas.

\section{Daftar Pustaka}

1. Kemenkes RI. Ditjen PP dan PL. Strategi Nasional Pengendalian TB di Indonesia. Jakarta: Depkes RI; 2014.

2. Dinas Kesehatan Provinsi Sumatera Utara. Profil Kesehatan Propinsi Sumatera Utara. Sumut; 2014.

3. Budiman, dkk. Hubungan Status Demografi Dengan Kepuasan Masyarakat Tentang Pelayanan Jamkesmas Di Wilayah Puskesmas Tanjugsari Kabupaten Bogor. Bogor : Jurnal Kesehatan Kartika; 2012.

4. Hariyanti. Hubungan Kepuasan Dengan Loyalitas Pasien di Unit Rawat Inap Rumah Sakit Umum Daerah Arifin Nu'mang Kabupaten Sidrap.Makassar; Universitas Hasanuddin; 2012.

5. Wibawani, dkk. Pengaruh Mutu Layanan Kesehatan Terhadap Kepuasan Pasien Rawat Inap Di Rumah Sakit Woodward Kota Palu. Makasar: Jurnal AKK, Vol 2 No 3. 2013.

6. Kiky M,dkk. Faktor Yang Berhubungan Dengan Kepuasan Pasien Rawat Jalan Di Puskesmas Rantepao Kabupaten Toraja Utara Tahun 2013. Makasar: FKM Universitas Hasanudin; 2013.

7. David. Hubungan Keterlambatan Kedatangan Dokter Terhadap Kepuasan Pasien Di Instalasi Rawat Jalan. Kediri: Jurnal Kedokteran Brawijaya; 2014.

8. Zuhdi F. Analisis Faktor Yang Berhubungan Dengan Kepuasan Pasien Rawat Inap Di Rumah Sakit Islam Surakarta. Surakarta: FIK UMS; 2013

9. Harianto NK dan Sudibyo S. Kepuasan Pasien Terhadap Pelayanan Resep di Apotek Kopkar Rumah Sakit Budhi Asih Jakarta, Majalah Ilmu Kefarmasian, Volume II (1), Jakarta; 2005. 